\title{
Discovery of a Small Molecule Insulin Receptor Activator
}

\author{
Gino M. Salituro, ${ }^{*}$ Fernando Pelaez, ${ }^{\dagger}$ and Bei B. Zhang ${ }^{\ddagger}$ \\ *Department of Natural Product Drug Discovery, ${ }^{\dagger}$ Department of Molecular Endocrinology, \\ R80W250, Merck Research Laboratories, Rahway, New Jersey 07065; ${ }^{t}$ Centro de Investigacion \\ Basica, Merck. Sharp \& Dohme de Espana, S.A. Josefa Valcarcel 38, Madrid 28027, Spain
}

\begin{abstract}
Insulin elicits diverse biological responses in many tissues and cell types by binding to its specific receptor. The insulin receptor (IR) is a tetramer consisting of two extracellular $\alpha$ subunits and two membrane-spanning $\beta$ subunits. The binding of insulin to the receptor causes conformational changes that lead to autophosphorylation and activation of the tyrosine kinase intrinsic to the $\beta$ subunits. Insulin receptor transphosphorylates several immediate substrates, resulting in modulation of a cascade of downstrearn signal transduction molecules. In order to discover small molecules that activate the human insulin receptor tyrosine kinase (IRTK), a cell-based assay was established and utilized to screen a collection of synthetic chemicals and natural product extracts. This effort led to the identification of a nonpeptidyl, small molecule, insulin-mimetic compound (demethylasterriquinone B-1, DMAQ-B1) that was isolated from a mixture of metabolites produced by a tropical endophytic fungus, Pseudomassaria sp. This compound induced human IRTK activation and increased tyrosine phosphorylation of IR $\beta$ subunit. It mediated insulin-like effects, including insulin receptor substrate-1 (IRS-1) phosphorylation and activation of phosphotidylinositide 3-kinase and Akt kinase. DMAQ-BI also exhibited an insulin-like effect on glucose uptake in adipocytes and skeletal muscle tissue. Furthermore, the compound was relatively selective for IR vs. insulin-like growth factor-I (IGF-I) receptor and other homologous receptor tyrosine kinases. In addition, it activated partially purified native IR or recombinant IR kinase, demonstrating the direct interaction of the small molecule with the IR. Oral administration of DMAQ-B1 resulted in significant glucose lowering in two mouse models of diabetes. Thus, DMAQ-B1 represents the first orally active insulin-mimetic agent. Pharmaceutical intervention aimed at augmenting IR function ultimately may prove beneficial as a novel therapeutic option in patients with diabetes.
\end{abstract}

\section{Introduction}

Diabetes is a chronic metabolic disorder affecting approximately five percent of the population of industrialized nations. Type 1 diabetes results from a ccllmediated autoimmune destruction of the $\beta$ cells of the pancreas, leading to absolute insulin deficiency. The more-prevalent form, type 2 diabetes, accounts for more than 90 percent of cases. The pathogenesis of type 2 diabetes is complex, involving progressive development of insulin resistance and a relative deficiency in insulin secretion, leading to overt hyperglycemia. 
Insulin elicits a diverse array of biological responses by binding to its specific receptor (White and Kahn, 1994). The insulin receptor (IR) is a heterotetrameric protein consisting of two extracellular $\alpha$ subunits and two transmembrane $\beta$ subunits. The binding of the ligand to the $\alpha$ subunit of IR not only concentrates insulin at its site of action but also induces conformational changes in the receptor. These changes, in turn, stimulate the tyrosine kinase activity intrinsic to the $\beta$ subunit of the IR. Extensive studies have indicated that the ability of the receptor to autophosphorylate and phosphorylate intracellular substrates is essential for its mediation of the complex cellular responses of insulin (Ellis et al., 1987; Kasuga et al., 1982; Rosen et al., 1983; Yu and Czech, 1984). Insulin receptors trans phosphorylate several immediate substrates (on Tyr residues), including insulin receptor substrate (IRS) proteins 1-4, Shc, and Gab 1, each of which provide specific docking sites for other signaling proteins containing Src homology 2 (SH2) domains (White and Yenush, 1998). These events lead to the activation of downstream signaling molecules, including phosphatidylinositol-3-kinase (PI-3kinase). Numerous studies have adduced that PI-3-kinase is required for the metabolic effects of insulin. Although the discrete pathways that couple PI-3-kinase to glucose regulation remain poorly defined, Akt (or protein kinase B), a Ser/Thr kinase known to be PI-3-kinase dependent, appears to be involved in insulin-mediated activation of glucose transport (Kohn et al., 1996) and glycogen synthesis (Alessi and Cohen, 1998).

Insulin is essential for maintaining glucose homeostasis and regulating carbohydrate, lipid, and protein metabolism (Rosen, 1989). The central role of the IR in metabolic and growth control has been validated in IR null mouse models (Accili et al., 1996; Joshi et al., 1996). Alterations of IR in specific tissues and/or insulin receptor substrate (IRS) 1 and 2 function via genetic manipulation have been shown to produce insulin resistance and diabetes in mice (Bruning et al., 1997a,1997b,1998; Kido et al., 2000; Kulkarni et al., 1999a,1999b; Lauro et al., 1998; Taylor, 1999). Decreased cellular responses to insulin or perturbation of the insulin signaling pathways are associated with a number of pathological states. Mutations in the IR gene - which lead to alterations of receptor synthesis, degradation, and function - have been described in patients with several uncommon syndromes associated with severe insulin resistance (Taylor, 1992). The molecular basis for insulin resistance that precedes, or is associated with, common forms of type 2 diabetes remains poorly understood. However, several studies have shown modest decreases in IR numbers attributed to downregulation in response to hyperinsulinemia in tissues or cells from type 2 diabetic patients (Caro et al., 1986; Olefsky, 1976). Substantial decreases in insulin-stimulated receptor tyrosine kinase (IRTK) activity and an even-more-substantial defect in receptormediated IRS phosphorylation or PI-3-kinase activation have been described using samples of tissue (e.g., muscle or fat) from rodents or human subjects with 
type 2 diabetes (Caro et al., 1987; Goodyear et al., 1995; Kerouz et al., 1997). Although controversial, diminished insulin-stimulated Akt activation was documented in skeletal muscle from type 2 diabetic patients (Kim et al., 1999; Krook et al., 1998). Thus, in patients with type 2 diabetes, clear defects exist that involve the IR and proximal steps in insulin signaling.

Discovery of oral insulin mimetic agents has been a long-standing yet elusive goal of pharmaceutical research. Given that most type 2 patients respond to insulinotropic agents or exogenously administered insulin, pharmaceutical intervention aimed at mimicking insulin's effect and augmenting IR function may prove beneficial. As patients with type I (insulin-dependent) diabetes are dependent upon parenteral, exogenous insulin injections for metabolic control, the discovery of orally active small molecules that might serve to mimic insulin's effects could lead to alternative therapies for this disorder.

\section{Discovery of DMAQ-B1 Through Screening of Natural Products}

\section{A. ASSAY}

A cell-based, 96-well screening assay was designed to identify small molecule IR activators. This assay utilizes Chinese hamster ovary cells (CHO.IR) that overexpress human IRs (Zhang et al., 1994). Following incubation of intact cells with insulin or test compounds, IRs are immunopurified using a monoclonal antibody specific for IR. Activation of insulin receptor is determined by measuring the IRTK activity towards an exogenous substrate (polyGlu:Tyr 4:1). This assay was employed to screen synthetic chemicals and natural product extracts to identify novel compounds capable of activating IR. Such an approach has advantages over a receptor-binding assay in that small molecules that compete with insulin binding are likely to be antagonists for the receptor. Furthermore, the assay was designed to identify compounds that work in intact cells, either by interacting directly with the receptor or by indirectly stimulating receptor activation (e.g., a specific phosphatase inhibitor).

\section{B. SOURCES OF NATURAL PRODUCTS}

Natural products historically have been a prolific source of therapeutically useful drugs. Approximately 160 marketed drugs utilized in a variety of disease states have been derived from natural sources. These include antibiotics (e.g., erythromycin, vancomycin, cephamycin, thienamycin, penicillins); antifungals (e.g., amphotericin B); immunosuppressants (e.g., FK 506, cyclosporin); antitumor agents (e.g., taxol, bleomycin, doxorubicin); antiparasitic agents (e.g., avermectin, milbemycin), and the cholesterol-lowering agent lovastatin. 
Several drugs derived from natural sources have been approved recently, including the anti-obesity compound tetrahydrolipstatin and the antibiotic streptogramin. Moreover, the antifungal lipopeptide known as caspofungin acetate (MK0991, CANCIDAS ${ }^{\mathrm{TM}}$ ), a semisynthetic derivative of the fungal metabolite pneumocandin $\mathrm{B}_{0}$, is now in phase III clinical trials. In the particular case of diabetes, a number of plant-derived secondary metabolites have been described to possess antidiabetic activity in a variety of model systems (Cignarella et al., 1996; Perez et al., 1997; Carney et al., 1999; Inman et aL, 1999).

In our screening program, over 50,000 samples of natural extracts were tested for their ability to mimic insulin activity using the assay described above. These extracts were obtained from more than 5000 microbial isolates recovered from diverse ecological niches (Figure 1). Substrates for microbial isolation were collected from a broad geographical range, covering both tropical and temperate regions. Fungal extracts were the predominant source of samples tested. The rationale behind focusing the screening on fungi is founded on the proven success of these microorganisms as a source of secondary metabolites (i.e., about 20,000 fungal metabolites are known to science, with 25 percent of them possessing biological activity) and the large sample pool from which to draw. Over 1.5 million species of fungi are thought to exist, with only 70,000 having been described (Hawksworth, 1991).

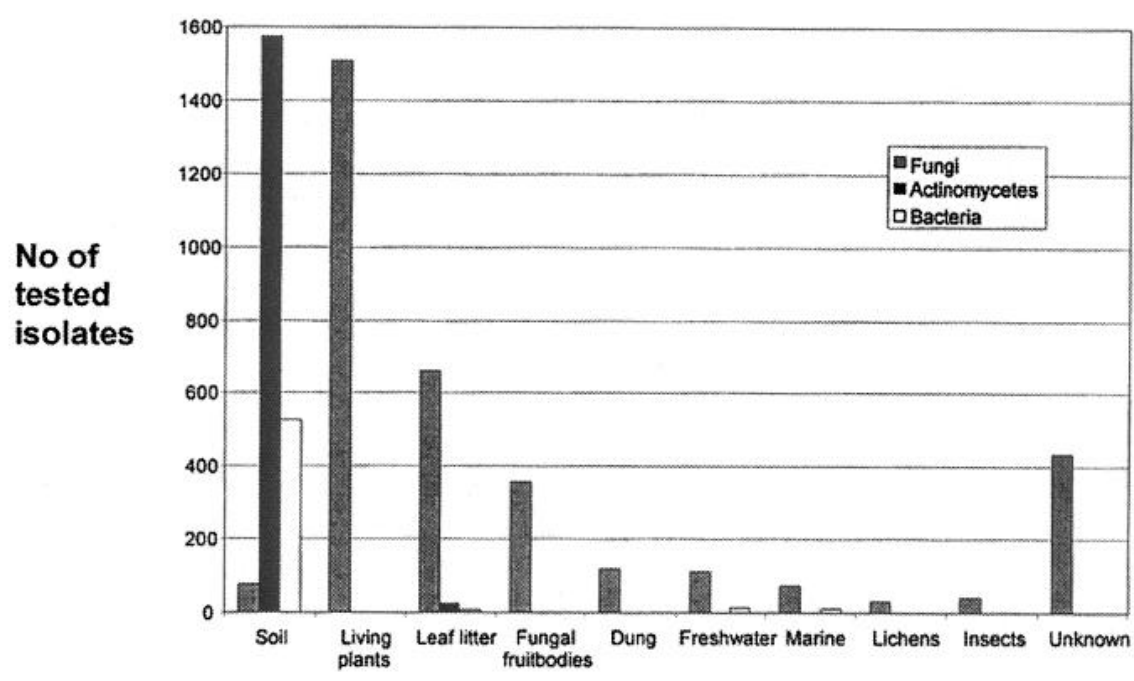

Substrate type

FIG. 1. Ecological distribution of microbial isolates tested in IRTK assay. 


\section{LEAD IDENTIFICATION AND ISOLATION}

In the course of screening microbial extracts in the cell-based IRTK activation assay, a sample obtained from the fermentation of a fungus isolated from unidentified living leaves collected near Kinshasa, Democratic Republic of Congo, was found to be moderately active. The fungus was recovered from the leaves using a standard surface sterilization technique for the isolation of endophytic fungi (Collado et al., 1996). This isolate (American Type Culture Collection 74411) was later tentatively identified as an undetermined species of the genus Pseudomassaria (Hyponectriaceae, incertae sedis, Ascomycota), based upon examination of an ascoma that was obtained by forcing the culture to grow on sterilized wood strips (G. Bills, unpublished results). Partial sequencing of the ribosomal DNA region, including the $18 \mathrm{~S}$ and 5.8S rRNA genes and the two internally transcribed spacers ITS1 and 1TS2, failed to provide a more-accurate identification for this strain. Pseudomassaria species typically are found growing on plant materials and are distributed in both tropical and temperate regions (Barr, 1964; Hyde et al., 1998). They had been never reported as producers of bioactive metabolites.

Seed cultures of Pseudomassaria sp. ATCC 74411 were prepared from slants grown on Difco Potato Dextrose Agar (PDA) at $25^{\circ} \mathrm{C}$ and 80 percent relative humidity (rh) for 14-2l days. The top third of one slant was aseptically transferred to a 250 -mL unbaffled flask containing $50 \mathrm{~mL}$ of a complex seed medium, then incubated on a shaker $(220 \mathrm{rpm})$ at $25^{\circ} \mathrm{C}$ and 80 percent rh for 4 days or until good growth was achieved. Two $\mathrm{mL}$ of a seed culture were used to inoculate 50 $\mathrm{mL}$ of production medium in $250-\mathrm{mL}$ Erlenmeyer flasks, which were incubated at $25^{\circ} \mathrm{C}, 220 \mathrm{rpm}, 80$ percent rh for 21 days (Zhang et al., 1999).

Interestingly, production of the IRTK-stimulating compound by the fungus appeared to be highly dependent on the culture conditions. Although the isolate was grown in as many as five different production media containing diverse nutritional components, the activity was recovered only in the medium described above.

For the isolation of the active compound present in the fermentation of Pseudomassaria sp. ATCC 74411, a 25-mL sample of whole broth was extracted with methylethyl ketone. A portion of the extract $(10 \mathrm{~mL})$ was dried $(250 \mathrm{mg})$ and purified by size exclusion chromatography on Sephadex LH-20 in methanol followed by semipreparative reverse-phase high-performance liquid chromotography (HPLC). The active compound crystallized as dark purple needles from ethyl acetate when stored in the cold $\left(4^{\circ} \mathrm{C}\right)$. Spectroscopic data: ${ }^{1} \mathrm{H},{ }^{13} \mathrm{C}$, correlation spectroscopy (COSY), heteronuclear multiple-quantum correlation (HMQC), heteronuclear mutiple-bond correlation (HMBC), and nuclear Overhauser effect spectroscopy (NOSEY) nuclear magnetic resonance (NMR) data and high-resolution fast atom bombardment mass spectroscopy (HRFABMS) were collected on 
$2.4 \mathrm{mg}$ of the major compound (Figure 2). Following data analysis, the compound was identified as demethylasterriquinone B-1, DMAQ-B1 (Figure 3), a member of the family of the asterriquinones (Yamamoto et al., 1976). The methylated analog asterriquinone B-1 had previously been isolated from Aspergillus terreus (Arai et al., 1981a). Ultimately, the structure of DMAQ-B1 was confirmed by a total synthesis of the compound (Liu et al., 1999).

The asterriquinones are widely known fungal bis-indolyl-quinones, structurally highly related to cochliodinoles (Jerram et al., 1975) and ochrindoles (De Guzman et al., 1994). These compounds have been found in many diverse, phylogenetically unrelated ascomycetes, including Aspergillus spp. (and the teleomorph Petromyces muricatus), Chaetomium spp., Chrysosporium merdarium, Humicola spp., and Botryotrichum spp. (De Guzman et al., 1994; Fredenhagen et al., 1997; Mocek et al., 1996; Ooike et al., 1997; Sekita, 1983). The asterriquinones and related bis-indolyl-quinones have been studied as potential antitumor agents because of their DNA-intercalating properties (Kaji et al., 1998; Yamamoto et al., 1976). Some of them are also HIV-1 protease inhibitors (Fredenhagen et al., 1997), antibacterial, and toxic to insects (De Guzman et al., 1994). Other biological activities reported for these molecules include inhibition of epidermal growth factor receptor (EGF-R) tyrosine kinase (Fredenhagen et al., 1997) and inhibition of the binding of the Grb-2 adapter to phosphorylated EGFR tyrosine kinase (Alvi et al., 1999). The compound found in our screening previously had been obtained by chemical treatment of asterriquinone B1 (Arai $e t$

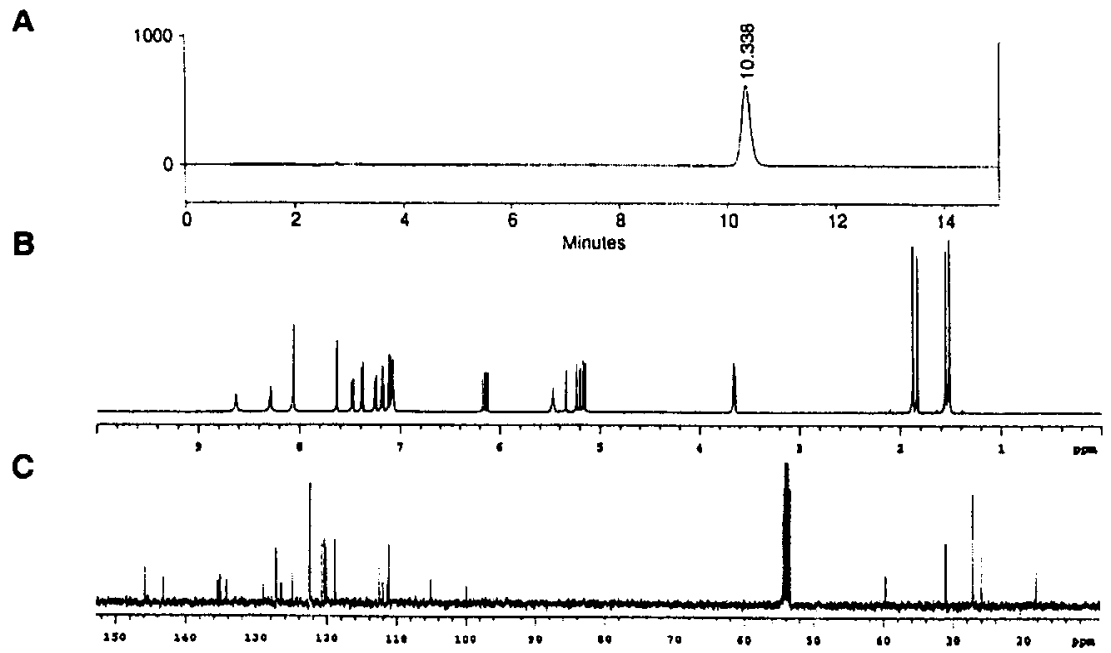

FIG. 2. Spectroscopic data on pure DMAQ-B1. (A) RP HPLC (Zorbax Rx C- $94.6 \times 250 \mathrm{~mm}$, $55: 45$ acetonitrile: $0.1 \%$ trifluroacetic acid $1 \mathrm{~mL} / \mathrm{min}$., $220 \mathrm{~nm}$ ). (B) $500 \mathrm{MHz}{ }^{1} \mathrm{H}_{\mathrm{NMR}}$ in $\mathrm{CD}_{2} \mathrm{Cl}_{2}$. (C) $125 \mathrm{MHz}{ }^{13} \mathrm{C} \mathrm{NMR}$ in $\mathrm{CD}_{2} \mathrm{Cl}_{2}$. 


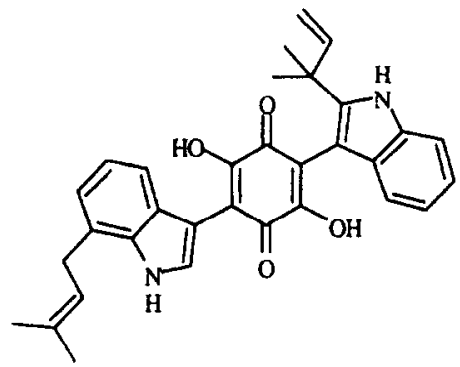

Demethylasterriquinone B1

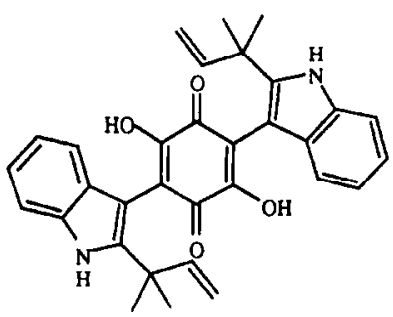

Hinnuliquinone

FIG. 3. Structures of demethylasterriquinone B-1 and hinnuliquinone.

al., 1981b) but its insulin-mimetic properties were unknown. Although asterriquinones seem to be widely distributed within the fungal kingdom, DMAQ-B1 has been found only once through several thousand fungal isolates screened. This suggests that, although the general metabolic pathway for the biosynthesis of asterriquinones may be present in many fungi, some of the specific steps involved in the synthesis of DMAQ-B1 could be much more restricted in nature.

In order to provide sufficient material for further biological testing, largescale fermentation and isolation methods were developed. A 120-liter batch of culture ATCC 74411 that contained approximated $630 \mathrm{mg} / \mathrm{L}$ of DMAQ-B1 was processed using a streamlined isolation procedure employing an adsorption-elution step, followed by liquid-liquid partitioning, and a single chromatography column (Figure 4). This yielded approximately $18 \mathrm{~g}$ of pure DMAQ-B1.

\section{ANALOGS (NATURAL PRODUCTS)}

This large-scale fermentation and isolation process led to the detection of a number of related minor components in the fermentation extracts. These components were purified by reverse-phase HPLC and their structures were elucidated using the same spectroscopic methods employed for the elucidation of DMAQ-B1 (Figure 5). Components 2 and 3 are most likely derived from alternate biosynthetic sequences, as they differ only in the functionality or number of isoprenyl sidechains on the indole rings. Components 4 and $\mathrm{S}$ can be envisioned as arising from oxidative transformations of DMAQ-B1. A major decomposition product also was observed in some aged solutions of DMAQ-B1. The appearance of this compound could be artificially accelerated under basic conditions $(\mathrm{pH}>10)$. 


\section{L WBE whole broth of Pseudomassaria}

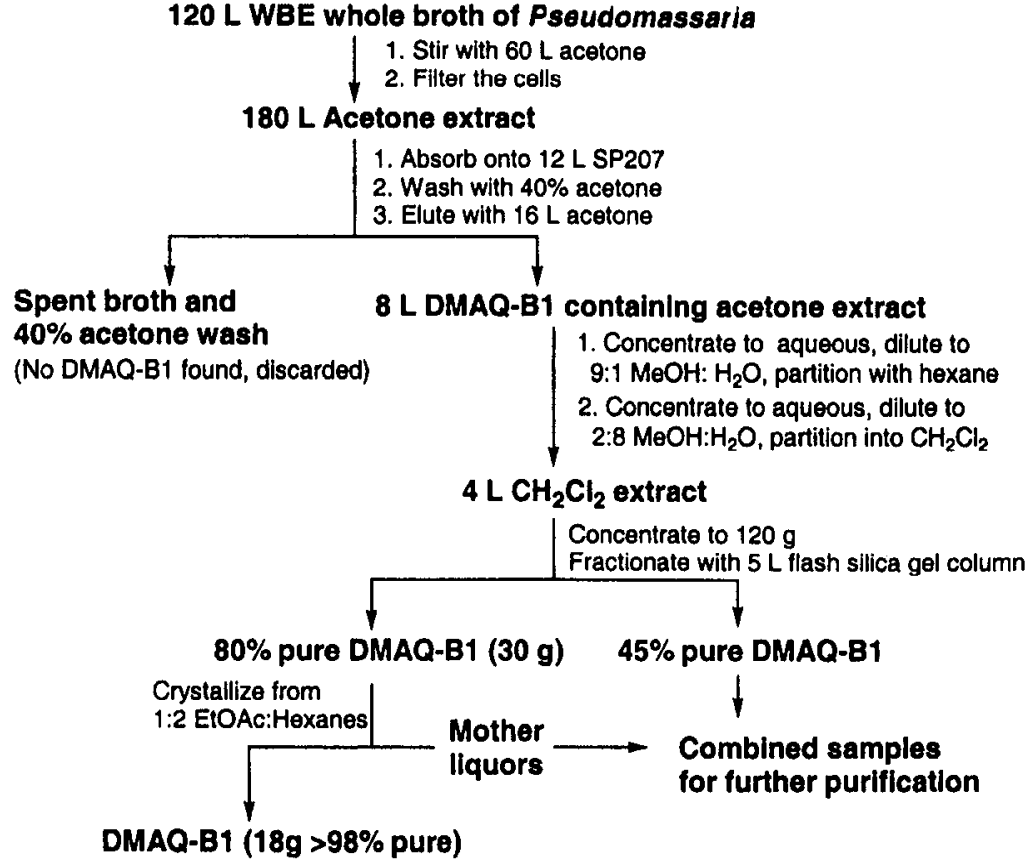

FIG. 4. Large-scale purification of DMAQ-B1 from Pseudomassaria fermentation.

\section{Biological Characterization of DMAQ-B1}

\section{A. ACTIVATION OF IR AND THE INSULIN SIGNALING PATHWAY}

In the cell-based IR activation assay, DMAQ-B1 was able to stimulate IRTK activity with 50 percent and 100 percent of the maximal activity achieved at 3-6 $\mathrm{uM}$ and 10-20 uM of compound concentrations, respectively (Figure 6A). The maximal IRTK activity induced by the compound was comparable to that stimulated by insulin. Hinulliquinone, the analog that is closely related in structure to DMAQ-B1, was about 100 times less potent in activating IRTK, suggesting that the effect of DMAQ-B1 is unlikely due to nonspecific effects exerted on cells by this class of compounds. When insulin was titrated in the assay in the presence of low concentrations of DMAQ-B1 (0.6 to $2 \mathrm{uM})$, there was a leftward shift of the insulin dose-response curve. This observation was consistent with the notion that DMAQ-B1 could function as an insulin sensitizer under the experimental conditions. 

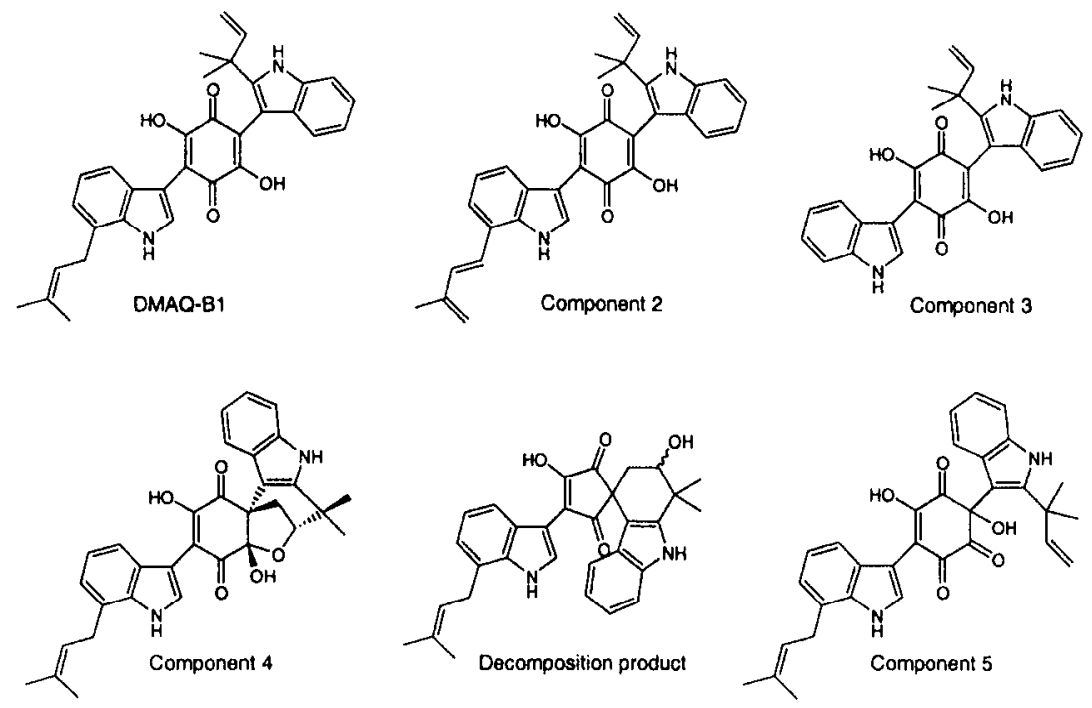
products.

FIG. 5. DMAQ-B1 and analogs isolated as minor fermentation components or degradation

DMAQ-B1 induced tyrosine phosphorylation of the IR $\beta$ subunit and IRS-1 in CHO.IR cells, as evidenced by antiphosphotyrosine immunoblotting (Figure $6 \mathrm{~B})$. Activation of these proximal insulin-signaling molecules was coupled to stimulation of other components of the signaling cascade. Thus, DMAQ-B1 stimulated PI-3-kinase activity (Endemann et al., 1990; Levy-Toledano et al., 1994) and phosphorylation of Akt kinase on the activating Ser-473 residue (Franke et al., 1995) in CHO.IR cells (Figure 7A and B). Moreover, DMAQ-B1 induced a classical insulin-like effect by acutely stimulating glucose uptake in rat primary adipocytes (263 percent of basal level at $10 \mu \mathrm{M}$ ) (Figure 7C) and in isolated soleus muscle from lean mice ( 237 percent of basal level at $2 \mu \mathrm{M}$ ) (Figure 7D). These results indicated that the small molecule, insulin-mimetic compound was capable of modulating multiple steps of the insulin signal transduction pathway.

\section{B. SELECTIVITY FOR IR}

Insulin receptor belongs to a superfamily of receptor tyrosine kinases with a high degree of sequence homology in the tyrosine kinase domain (Ullrich and Schlessinger, 1990). This family includes the IR and the receptors for growth factors such as insulin-like growth factor-I (IGF-I), EGF, and platelet-derived growth factor (PDGF). Activation of receptor tyrosine kinases leads to a wide 


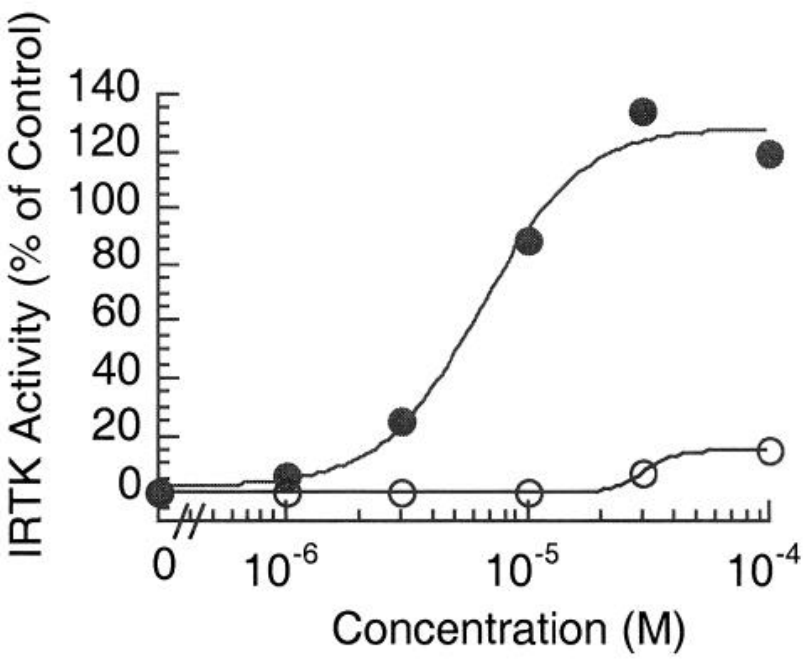

B

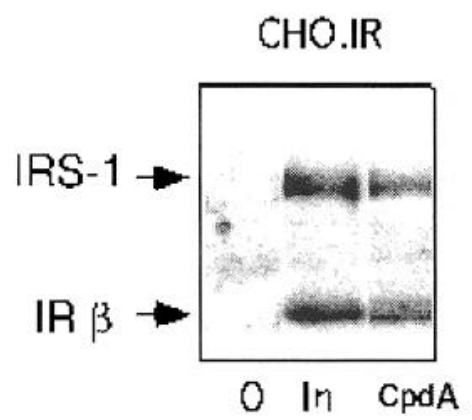

FIG. 6. Activation of IRTK in CHO.IR cells. (A) Dose- response curves are shown for DMAQB1 (filled circles) and hinulliquinone (open circles). (B) Stimulation of tyrosine phosphorylation of IRS- 1 and $\beta$ subunits of IR in CHO.IR cells by DMAQ-B1 (cpd A). [Reprinted with permission from Zhang, B., Salituro, G., Szalkowski, D., Li, Z., Zhang, Y., Royo, I., Vilella, D., Pelaez, F., Ruby, C., Kendall, R., Mao, X., Griffin, P., Calaycay, J., Heck, J.V., Smith, R.G., and Moller, D. Science 284, 974-977, 1999. Copyright 1999 American Association for the Advancement of Science.] 
A

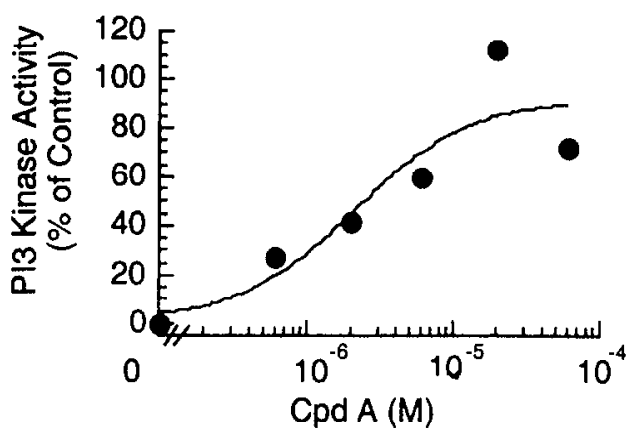

B

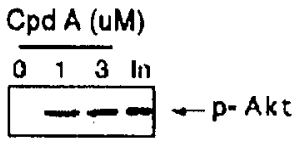

C
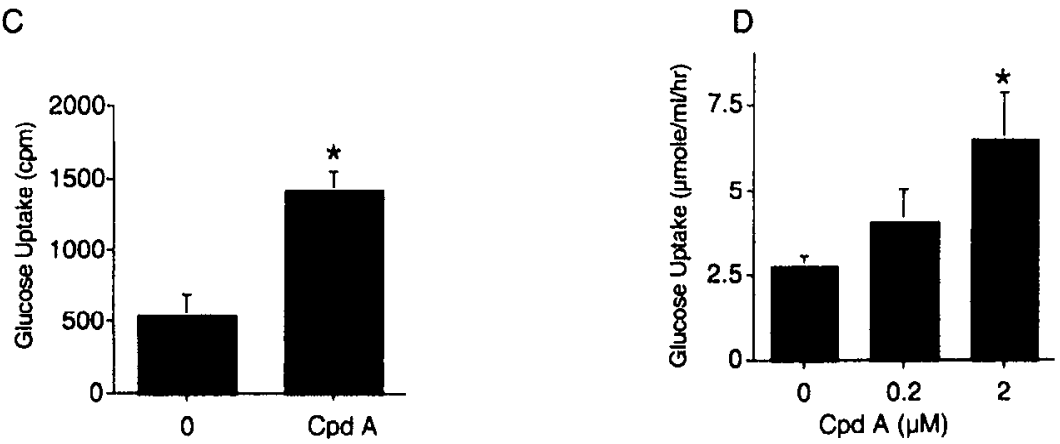

FIG. 7. Activation of insulin signaling pathway in cells treated with DMAQ-B1. (A) Activation of PI-3-kinase in CHO.IR cells. (B) Stimulation of phosphorylation of Akt in CHO.IR cells. (C) Glucose uptake in rat primary adipocytes. (D) Glucose uptake in isolated soleus muscles. ${ }^{*}, p<0.02$ by student $t$ test. [Reprinted with permission from Zhang, B., Salituro, G., Szalkowski, D., Li, Z., Zhang, Y., Royo, I., Vilella, D., Pelaez, F., Ruby, C., Kendall, R., Mao, X., Griffin, P., Calaycay, J., Heck, J.V., Smith, R.G., and Moller, D. Science 284, 974-977, 1999. Copyright 1999 American Association for the Advancement of Science.] 
variety of beneficial biological effects, ranging from metabolic regulation to embryonic development to tissue regeneration. These receptor tyrosine kinases also play pivotal roles in pathological conditions, including diabetic retinopathy, atherosclerosis, and deleterious neoplastic transformation. Thus, a critically important aspect in the search for small molecules capable of activating IRTK is to determine the selectivity of such compounds. Although these tyrosine kinases are highly homologous, small variations in primary sequences have provided the basis for identification of potent and exquisitely selective inhibitors (Fry and Bridges, 1995; Fry et al., 1994; Levitzki and Gazit, 1995; Mohammadi et al., 1996, 1997,1998).

In order to determine the specificity of test compounds for IR vs. other selected homologous receptors, parallel, cell-based assays were established and used to counterscreen IR activators against IGF-I-R, EGF-R, and PDFG-R. In CHO cells overexpressing IGF-I-R (CHO.IGFIR), DMAQ-B1 (at $10 \mu \mathrm{M}$ ) did not stimulate IGF-I-R or IRS-1 tyrosyl phosphorylation. No other compound-mediated tyrosyl protein phosphorylation was evident, suggesting that the compound is selective for IR vs. IGF-I-R activation. In subsequent studies using CHO.IGFIR cells, EGF-R-overexpressing cells (CHO.EGFR), and quantitative tyrosine kinase (IGF-I-R) or anti-phosphotyrosine ELISA (EGF-R) assays, DMAQ-BI was

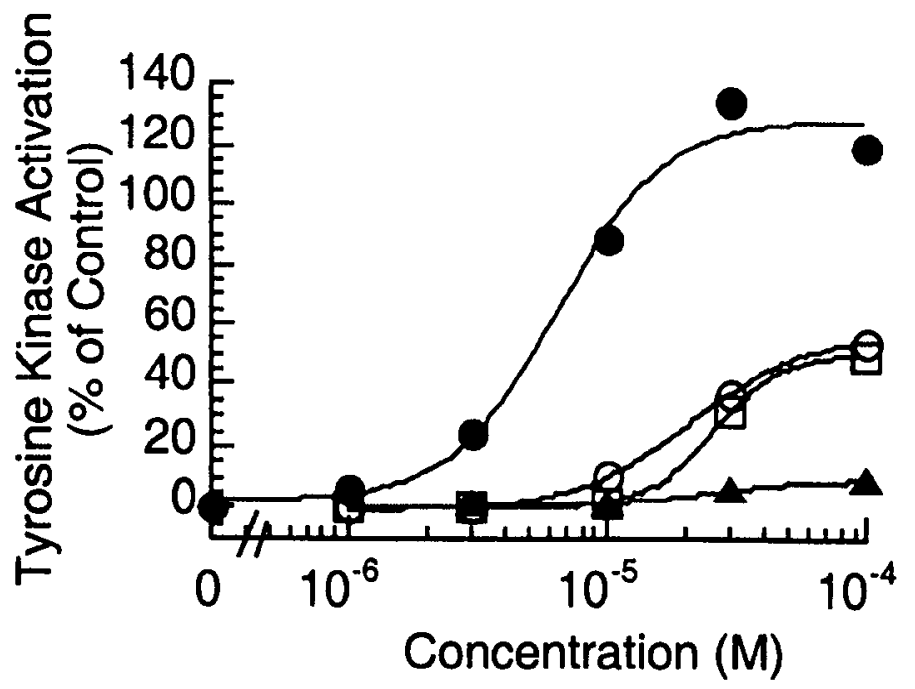

FIG. 8. Selectivity of DMAQ-B1. Activation of IRTKs by DMAQ-B1 in CHO.IR (filled circles), CHO.IGFIR (open circles), CHO.EGFR (open squares), or CHO.PDGFR (filled triangles) cells. [Reprinted with permission from Zhang, B., Salituro, G., Szalkowski, D., Li, Z., Zhang, Y., Royo, I., Vilella, D., Pelaez, F., Ruby, C., Kendall, R., Mao, X., Griffin, P., Calaycay, J., Heck, J.V., Smith, R.G., and Moller, D. Science 284, 974-977, 1999. Copyright 1999 American Association for the Advancement of Science.] 
shown to induce weak IGF-I-R and EGF-R activation; $100 \mu \mathrm{M}$ concentrations were required to achieve 50 percent efficacy of either IGF-I or EGF (Figure 8). In addition, DMAQ-Bl did not induce EGF-R activation (up to $60 \mu \mathrm{M}$ ) in cells (A431) that express high levels of endogenous EGF-Rs (not shown). The compound (up to $100 \mu \mathrm{M}$ ) also failed to induce detectable activation of PDGF-R in overexpressing $\mathrm{CHO}$ cells (Figure 8) or fetal human fibroblasts, which express high endogenous PDGF-R levels (not shown). Based on these data, DMAQ-B1 has greater than 10 -fold selectivity for IR and may provide a scaffold for building in greater selectivity.

\section{DIRECT INTERACTION WITH IR}

To establish that the effect of DMAQ-BI observed in the cell-based assays is due to direct activation of IR, experiments were conducted to study the compound's mechanism of action. Several lines of evidence suggested that DMAQ-B1 acted directly to activate the IR intracellular $\beta$ subunit (tyrosine kinase domain). First, transfected $\mathrm{CHO}$ cells (CHO.IRR/IR) that overexpress chimeric receptors composed of the IR intracellular domain fused to the nonhomologous insulin receptor-related receptor (IRR) extracellular domain (Zhang and Roth, 1992) were used to show that DMAQ-B1 (but not insulin) could activate receptor tyrosine kinase activity in intact cells (Figure 9A). Second, DMAQ-BI did not displace radiolabeled insulin binding to IRs expressed in intact CHO.IR cells, nor was the affinity of insulin for the receptor affected (Figure 9B). Third, direct, in vitro incubation with DMAQ-B1, but not compound $\mathrm{B}$, was able to increase tyrosine kinase activity of recombinant IRTK protein (Figure 9C). Furthermore, IR was partially purified from CHO.IR cells using wheat germ agglutanin (WGA) affinity chromatography. When the partially purified IR was incubated in the presence of $\gamma^{32}$ P-ATP and a 12-mer IR peptide substrate, DMAQ-B1 stimulated IR kinase activity in a dose-dependent manner, as measured by increased incorporation of radiolabel into the substrate peptide (Figure 9D).

The mechanism for activation of IRTK has been a subject of intensive investigation. High-resolution structural information has been obtained through crystallographic studies of the IR kinase domain (Hubbard et al., 1994; Hubbard, 1997). Based on crystal structures of the unphosphorylated, low-activity form as well as the phosphorylated, active form of IR - a model of cis-inhibition and trans-activation of the receptor was proposed. The unliganded receptors exist in the autoinhibitory conformation that prevents access of ATP and substrate to the active site. Upon autophosphorylation of Tyr1158, Tyr1162, and Tyr1163 in the activation loop, the IR kinase undergoes a major conformational change, resulting in unrestricted access of adenosine triphosphate (ATP) and substrate to the active site and full activation of the kinase. More recently, the three-dimensional (3D) structure of IR bound to insulin was determined by electron cryomicroscopy (Luo 


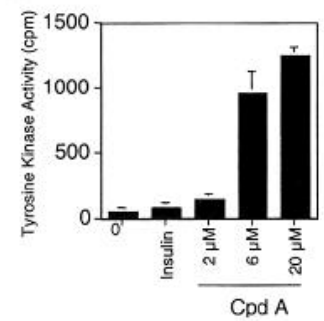

B

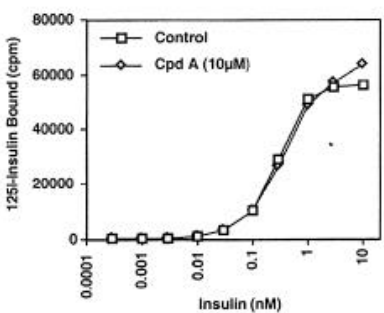

Histone $\mathrm{H} 2 \mathrm{~B}$
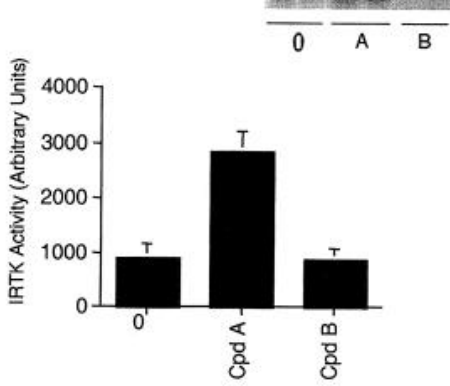

D

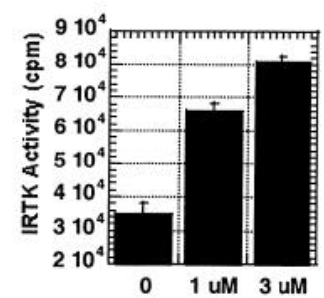

FIG. 9. Interaction of DMAQ-B1 with IR. (A) Activation of tyrosine kinase in CHO cells expressing IRR/IR chimeric receptor. (B) Lack of effect of DMAQ-B1 on insulin binding to the receptor. (C) In vitro activation of recombinant IRTK. (D) Activation of partially purified insulin receptor by DMAQ-B1. [Modified with permission from Zhang, B., Salituro, G., Szalkowski, D., Li, Z., Zhang, Y., Royo, I., Vilella, D., Pelaez, F., Ruby, C., Kendall, R., Mao, X., Griffin, P., Calaycay, J., Heck, J.V., Smith, R.G., and Moller, D. Science 284, 974-977, 1999. Copyright 1999 American Association for the Advancement of Science.] 
et al., 1999). The 3D reconstruction of the quaternary structure reveals that both $\alpha$ subunits are involved in insulin binding and that the two $\beta$ subunits are poised for trans-autophosphorylation. These structural studies have provided the molecular basis of IR activation.

In order to assess whether interaction of DMAQ-B1 with IRTK domain could alter conformation of the protein, recombinant IR intracellular domain protein (48 $\mathrm{kDa}$ ) was incubated with DMAQ-B1, followed by partial protease digestion. This approach revealed that the compound induced a change in protease sensitivity of IRTK, as illustrated by altered proteolytic pattern of the protein (Figure 10). A different pattern of altered protease sensitivity was observed following incubation of protein with an ATP analog (ATP $\gamma$-S), which is known to affect IR kinase conformation (Hubbard, 1997; Hubbard et al., 1994). A third protease digestion pattern was observed following combined incubation with DMAQ-B1 and ATP $\gamma-$ $\mathrm{S}$. Of particular interest was the presence of a $30-\mathrm{kDa}$ band when the $48-\mathrm{kDa}$ protein was incubated with DMAQ-B1 followed by partial trypsin digestion

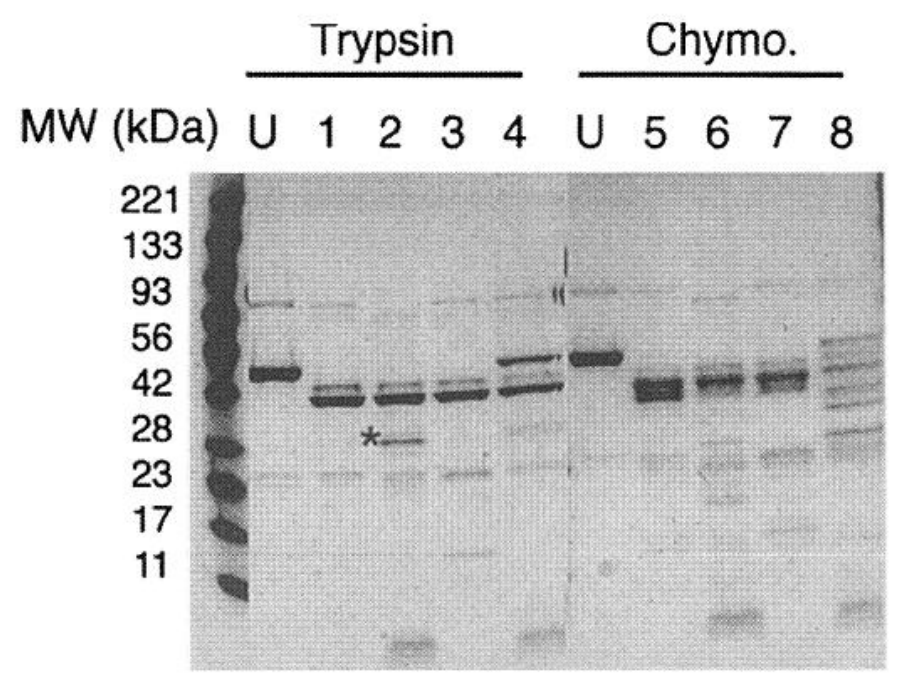

FIG. 10. DMAQ-B1 alters protease sensitivity of recombinant IR intracellular domain protein. The 48-kDa IRTK protein was subject to limited trypsin or chymotrypsin (chymo.) digestion in the presence or absence of compounds. The digestion mixtures were separated with electrophoresis and the gels were stained with Commassie Blue. $\mathrm{U}=$ undigested protein; lanes $1,5=\mathrm{DMSO}$ control; lanes 2, 6 = DMAQ-B1; lanes 3, 7 = ATP $\gamma$-S; lanes 4, 8 = DMAQ-B1 plus ATP $\gamma$-S. [Reprinted with permission from Zhang, B., Salituro, G., Szalkowski, D., Li, Z., Zhang, Y., Royo, I., Vilella, D., Pelaez, F., Ruby, C., Kendall, R., Mao, X., Griffin, P., Calaycay, J., Heck, J.V., Smith, R.G., and Moller, D. Science 284, 974-977, 1999. Copyright 1999 American Association for the Advancement of Science.] 
(denoted by $*$ in lane 2). Further experiments with titration of the protease showed that 10 to $50 \times$ decreased concentrations of trypsin could produce the approximately $30-\mathrm{kDa}$ digestion product in the presence of DMAQ-B1. The trypsin digestion products were separated and visualized in a Coomassie-blue stained $4 \%-20 \%$ SDS polyacrylamide gel. Following electrotransfer onto a polyvinylidene difluoride (PVDF) membrane, the 30-kDa band was excised and subjected to automated Edman sequence analysis to reveal the $\mathrm{N}$-terminal peptide sequence - $\mathrm{T}^{1031}$ VNESASL. This peptide is immediately adjacent to $\mathrm{K}^{1030}$, which has been shown to be involved in ATP binding to the active site of the IRTK domain (Chou et al., 1987; Ebina et al., 1985,1987; McClain et al., 1987). Thus, interaction of DMAQ-B1 with the IRTK domain apparently altered the conformation of the protein in the region encompassing the ATP binding site. This could conceivably lead to activation of the kinase by partially relieving the cis-inhibition of the enzyme. Structural biology studies will be necessary to further elucidate the mechanism of action.

\section{ANTIDIABETIC ACTIVITY IN MURINE MODELS OF DIABETES}

The results of in vitro experiments demonstrated that DMAQ-B1 is an insulin mimetic with selectivity for IR in cell-based assays, suggesting that it might exhibit substantial glucose-lowering effects in vivo. This hypothesis was tested using $\mathrm{db} / \mathrm{db}$ and ob/ob mice, obese animal models of type 2 diabetes characterized by severe insulin resistance and hyperglycemia. The purpose of the in vivo studies was to determine the potential ability of DMAQ-B1 to correct the diabetic state in the mouse models without resulting in undesirable side effects.

Oral administration of DMAQ-B1 to diabetic $\mathrm{db} / \mathrm{db}$ mice was shown to be efficacious for lowering the elevated blood glucose. Single-dose, oral administration of DMAQ-B1 resulted in dose-dependent glucose lowering (Figure 11A), with over 50 percent transient correction of hyperglycemia achieved at 25 $\mathrm{mg} / \mathrm{kg} /$ day (over 3-6 hours; food withheld). In addition, chronic, daily, oral administration of DMAQ-B1 (at 5 or $20 \mathrm{mg} / \mathrm{kg} /$ day) for 7 days was shown to result in significant correction of hyperglycemia in ad libitum-fed $\mathrm{db} / \mathrm{db}$ mice (Figure 11B). The in vivo effects of DMAQ-B1 on blood glucose levels in $\mathrm{db} / \mathrm{db}$ mice also were shown to be independent of potential effects on circulating insulin or glucagon (not shown) and were clearly evident in food-withheld mice where changes in feed intake were not a factor. In addition, when DMAQ-B1 was administered to ob/ob mice with extreme hyperinsulinemia and mild hyperglycemia, followed by a glucose tolerance test, significant and dose-dependent reductions in glucose excursion were observed (Figure 11C). Single, oral doses of DMAQ-B1 also acted to suppress elevated plasma insulin levels in ob/ob mice (Figure 11D). Chronic treatment of mice (up to 15 days) with therapeutic doses of DMAQ-B1 did not affect food intake, body weight, organ weights, or blood 
A
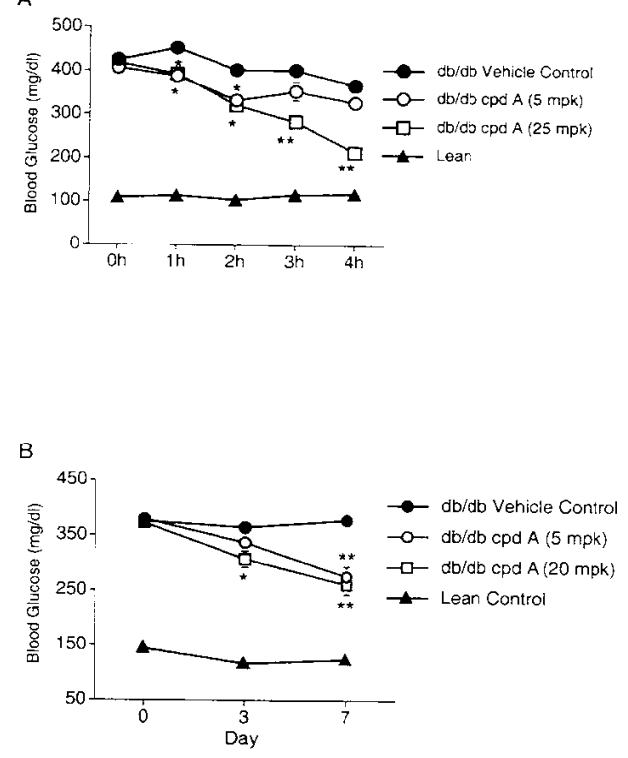

$\mathrm{C}$
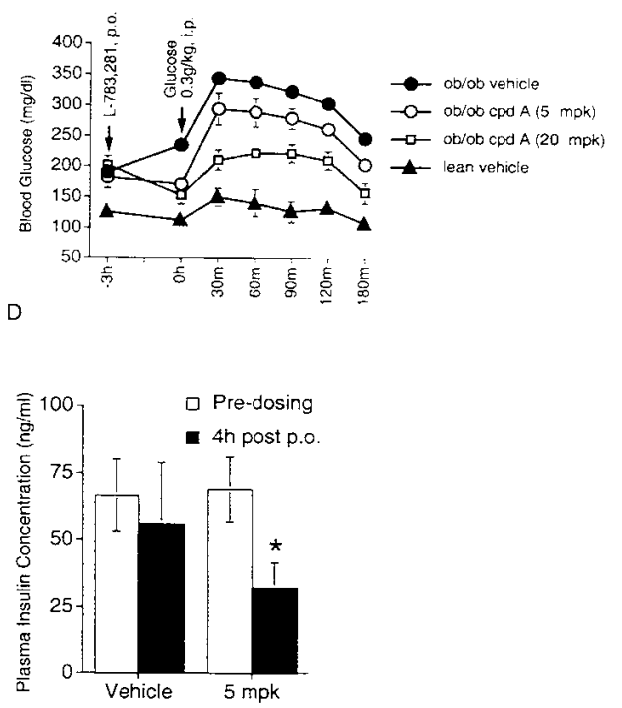
in $\mathrm{db} / \mathrm{db}$ mice following chronic dosing. (C) Glucose tolerance test in ob/ob mice. (D) Plasma insulin level in 12-week-old ob/ob mice at pre- and 4-hour post single oral dosing of DMAQ-B1. Shown are mean \pm S.E.M. values for each data point ( $\mathrm{n}=7-9$ for each group). In some cases, S.E.M. values are within the area of the symbols. ${ }^{*}, \mathrm{p}<0.05 ;{ }^{* *} \mathrm{p}<0.002$ by student $t$ test. All animals were fed ad libitum prior to the study and animal care was in accordance with institutional guidelines. [Modified with permission from Zhang, B., Salituro, G., Szalkowski, D., Li, Z., Zhang, Y., Royo, I., Vilella, D., Pelaez, F., Ruby, C., Kendall, R., Mao, X., Griffin, P., Calaycay, J., Heck, J.V., Smith, R.G., and Moller, D. Science 284, 974-977, 1999. Copyright 1999 American Association for the Advancement of Science.] 
chemistry values. These data indicate that DMAQ-B1 functions as an efficacious antidiabetic agent in murine NIDDM models.

Vanadate is another orally active compound that can function as an insulin mimetic agent (Goldfine et al., 1995). Unlike the IR activator exemplified by DMAQ-B1, vanadate inhibits protein tyrosine phosphatases (PTP) and augments tyrosyl phosphorylation of a wide variety of cellular proteins, including the IR (Huyer et al., 1997). Recent studies indicate that PTP1B plays an important role in modulating insulin signaling, since augmented insulin sensitivity was observed in PTP1B knockout mice (Elchebly et al., 1999). Interestingly, PTP1B null mice also were protected from obesity. Therefore, specific inhibitors of PTP1B represent a potential treatment for diabetes or other metabolic disorders by augmenting activity of the IRTK.

\section{Summary}

The discovery of DMAQ-B1 demonstrated that a small, nonpeptidyl molecule is capable of mimicking the in vitro and in vivo function of a protein hormone by interacting with and activating its receptor. It is worth noting that small molecule agonists have been identified for other peptidyl hormone receptors such as erythropoeitin and granulocyte colony-stimulating factor receptors (Johnson $e t$ al., 1998; Livnah et al., 1996; Tian et al., 1998). These agonists interact with the extracellular ligand-binding domain and induce dimerization of the monomeric receptor subunits, leading to activation of the receptors. Selective IR activators, as exemplified by DMAQ-B1, may lead to the development of a novel class of antidiabetic agents.

\section{REFERENCES}

Accili, D., Drago, J., Lee, E.J., Johnson, M.D., Cool, M.H., Salvatore, P., Asico, L.D., Jose, P.A., Taylor, S.I., and Westphal, H. (1996). Nature Genet. 12, 106-109.

Alessi, D.R., and Cohen, P. (1998). Curr. Opin. Genet. Devel. 8, 55-62.

Alvi, K.A., Pu, H., Luche, M., Rice, A., App, H., McMahon, G., Dare, H., and Margolis, B. (1999). J. Antibiotics 52, 215-223.

Arai, K., Shimizu, S., Taguchi, Y., and Yamamoto, Y. (1981a). Chem. Pharmacol. Bull. 29, 991-999.

Arai, K., Masuda, K., Kiriyama, N., Nitta, K., Yamamoto, Y., and Shimizu, S. (198lb). Chem. Pharmacol. Bull. 29, 961-969.

Barr, M.E. (1964). Mycologia 56, 841-862.

Bruning, J.C., Winnay, J., Bonner-Weir, S., Taylor, S.I., Accili, D., and Kahn, C.R. (1997a). Cell 88, $561-572$.

Bruning, J.C., Winnay, J., Cheatham, B., and Kahn, C.R. (1997b). Mol. Cell Biol. 17, 1513-1521.

Bruning, J.C., Michael, M.D., Winnay, J.N., Hayashi, T., Horsch, D., Accili, D., Goodyear, L.J., and Kahn, C.R. (1998). Mol. Cell 2, 559-569.

Carney, J.R., Krenisky, J.M., Williamson, R.T., Luo, J., Carlson, T.J., Hsu, V.L., and Moswa, J.L. (1999). J. Nat. Products 62, 345-347. 
Caro, J.F., Itoop, O., Pories, W.J., Meelheim, D., Flickinger, E.G., Thomas, F., Jenquin, M., Silverman, J.F., Khazanie, P.G., and Sinha, M.K. (1986). J. Clin. Invest. 78, 249-258.

Caro, J.F., Sinha, M.K., Raju, S.M., Itoop, O., Pories, W.J., Flickinger, E.G., Meelheim, D., and Dohm, G.L. (1987). J. Clin. Invest. 79, 1330-1337.

Chou, C.K., Dull, T.J., Russell, D.S., Gherzi, R., Lebwohl, D., Ullrich, A., and Rosen, O.R. (1987). J. Biol. Chem. 262, 14663-14667.

Cignarella, A., Nastasi, M., Cavalli, E., and Puglisi, L. (1996). Thrombasis Res. 84, $311-322$

Collado, J., Platas, G., and Pelaez, F. (1996). Nova Hedwigia 63, 347-360.

De Guzman, F.S., Bruss, D.R., Rippentrop, J.M., Gloer, K.B., Gloer, J.B., Wicklow, D.T., and Dowd, P.F. (1994). J. Nat. Products 57, 634-639.

Ebina, Y., Ellis, L., Jarnagin, K., Edery, M., Graf, L., Clauser, E., Ou, J.H., Masiarz, F., Kan, Y.W., Goldfine, I.D., Roth, R.A., and Rutter, W.J. (1985). Cell 40, 747-758.

Ebina, Y., Araki, E., Taira, M., Shimada, F., Mori, M., Craik, C.S., Siddle, K., Pierce, S.B., Roth, R.A. and Rutter, W.J. (1987). Proc. Natl. Acad. Sci. U.S.A. 84, 704-708.

Elchebly, M., Payette, P., Michaliszyn, E., Cromlish, W., Collins, S., Loy, A.L., Normandin, D., Cheng, A., Himms-Hagen, J., Chan, C.C., Ramachandran, C., Gresser, M.J., Tremblay, M.L., and Kennedy, B.P. (1999). Science 283, 1544-1548.

Ellis, L., Morgan, D.O., Clauser, E., Roth, R.A., and Rutter, W.J. (1987). Mol. Endocrinol. 1, 15-24.

Endemann, G., Yonezawa, K., and Roth, R.A. (1990). J. Biol. Chem. 265, 396-400.

Franke, T.F., Yang, S.I., Chan, T.O., Datta, K., Kazlauskas, A., Morrison, D.K., Kaplan, D.R., and Tsichlis, P.N. (1995). Cell 81, 727-736.

Fredenhagen, A., Petersen, F., Tintelnot-Blomley, M., Rosel, J., Mett, H., and Hug, P. (1997). J. Antibiotics 59, 395-401.

Fry, D.W., and Bridges, A.J. (1995). Curr. Opin. Biotechnol. 6, 662-667.

Fry, D.W., Kraker, A.J., McMichael, A., Ambroso, L.A., Nelson, J.M., Leopold, W.R., Connors, R.W., and Bridges, A.J. (1994). Science 265, 1093-1095.

Goldfine, A.B., Simonson, D.C., Folli, F., Patti, M.E., and Kahn, C.R. (1995). Mol. Cell Biochem. 153, $217-23 !$.

Goodyear, L.J., Giorgino, F., Sherman, L.A., Carey, J., Smith, R.J., and Dohm, G.L. (1995). J. Clin. Invest. 95, 2195-2204.

Hawksworth, D.L. (1991). Mycol. Res. 95, 641-655.

Hubbard, S.R. (1997). EMBO J. 16, 5572-5581

Hubbard, S.R., Wei, L., Ellis, L., and Hendrickson, W.A. (1994). Nature 372, 746-754.

Huyer, G., Liu, S., Kelly, J., Moffat, J., Payette, P., Kennedy, B., Tsaprailis, G., Gresser, M.J., and Ramachandran, C. (1997). J. Biol. Chem. 272, 843-851.

Hyde, K.D., Frohlich, J. and Taylor, J.E. (1998). Sydowia 50, 21-80.

Inman, W.D., Luo, J., Jolad, S.D., King, S.R., and Cooper, R. (1999). J. Nat. Products 62, 1088-1092.

Jerram, W.A., Mclnnes, A.G., Maass, W.S.G., Smith, D.G., Taylor, A., and Walter, J.A. (1975). Can J. Chem. 53, 727-737.

Johnson, D.L., Farrell, F.X., Barbone, F.P., McMahon, F.J., Tullai, J., Hoey, K., Livnah, O., Wrighton, N.C., Middleton, S.A., Loughney, D.A., Stura, E.A., Dower, W.J., Mulcahy, L.S., Wilson, I.A., and Jolliffe, L.K. (1998). Biochemistry 37, 3699-3710

Joshi, R.L., Lamothe, B., Cordonnier, N., Mesbah, K., Monthioux, E., Jami, J., and Bucchini, D. (1996). EMBO J. 15, 1542-1547.

Kaji, A., Iwata, T., and Kiriyama, N. (1998). J. Antibiotics 51, 235-238.

Kasuga, M., Karlsson, F.A., and Kahn, C.R. (1982). Science 215, 185-187.

Kerouz, N.J., Horsch, D., Pons, S., and Kahn, C.R. (1997). J. Clin. Invest. 100, 3164-3172.

Kido, Y., Burks, D.J., Withers, D., Bruning, J.C., Kahn, C.R., White, M.F., and Accili, D. (2000). J. Clin. Invest. 105, 199-205. 
Kim, Y.B., Zhu, J.S., Zierath, J.R., Shen, H.Q., Baron, A.D., and Kahn, B.B. (1999). Diabetes 48, 310-320.

Kohn, A.D., Summers, S.A., Birnbaum, M.J., and Roth, R.A. (1996). J. Biol. Chem. 271, 31372-31378.

Krook, A., Roth, R.A., Jiang, X.J., Zierath, J.R., and Wallberg-Henriksson, H. (1998). Diabetes 47, 1281-1286.

Kulkarni, R.N., Bruning, J.C., Winnay, J.N., Postic, C., Magnuson, M.A., and Kahn, C.R. (1999a). Cell 96, 329-339.

Kulkarni, R.N., Winnay, J.N., Daniels, M., Bruning, J.C., Flier, S.N., Hanahan, D., and Kahn, C.R. (1999b). J. Clin. Invest. 104, R69-R75.

Lauro, D., Kido, Y., Castle, A.L., Zarnowski, M.J., Hayashi, H., Ebina, Y., and Accili, D. (1998). Nature Genet. 20, 294-298.

Levitzki, A., and Gazit, A. (1995). Science 267, 1782-1788.

Levy-Toledano, R., Taouis, M., Blaettler, D.H., Gorden, P., and Taylor, S.I. (1994). J. Biol. Chem. 269, 31178-31182

Liu, K., Wood, H.B., and Jones, A.B. (1999). Tetrahedron Lett. 40, $5119-5122$.

Livnah, O., Stura, E.A., Johnson, D.L., Middleton, S.A., Mulcahy, L.S., Wrighton, N.C., Dower, W.J., Jolliffe, L.K., and Wilson, I.A. (1996). Science 273, 464-471.

Luo, R.Z., Beniac, D.R., Fernandes, A., Yip, C.C., and Ottensmeyer, F.P. (1999). Science 285, 1077-1080.

McClain, D.A., Maegawa, H., Lee, J., Dull, T.J., Ullrich, A., and Olefsky, J.M. (1987). J. Biol. Chem. 262, 14663-14671.

Mocek, U., Schultz, L., Buchan, T., Baek, C., Fretto, L., Nzerem, J., Sehl, L., and Sinha, U. (1996). J. Antibiotics 49, 854-859.

Mohammadi, M., Schlessinger, J., and Hubbard, S.R. (1996). Cell 86, 577-587.

Mohammadi, M., McMahon, G., Sun, L., Tang, C., Hirth, P., Yeh, B.K., Hubbard, S.R., and Schlessinger, J. (1997). Science 276, 955-960.

Mohammadi, M., Froum, S., Hamby, J.M., Schroeder, M.C., Panek, R.L., Lu, G.H., Eliseenkova, A.V., Green, D., Schlessinger, J., and Hubbard, S.R. (1998). EMBOJ. 17, 5896-5904.

Olefsky, J.M. (1976). J. Clin. Invest. 57, 1165-1172.

Ooike, M., Nozawa, K., Udagawa, S., and Kawai, K. (1997). Chem. Pharm. Bull. 45, 1694-1696.

Perez, S.G., Perez, R.M.G., Perez, C.G., Zavala, M.A.S., and Vargas, R.S. (1997). Pharm. Acta Helv. 72, 105-111

Rosen, O.M. (1989). Diabetes 38, 1508-1511.

Rosen, O.M., Herrera, R., Olowe, Y., Petruzzelli, M., and Cobb, M.H. (1983). Proc. Natl. Acad. Sci. U.S.A. 80, 3237-3240.

Sekita, S. (1983). Chem. Pharm. Bull. 31, 2998-3001.

Taylor, S.I. (1992). Diabetes 41, 1473-1490.

Taylor, S.I. (1999). Cell 97, 9-12.

Tian, S.S., Lamb, P., King, A.G., Miller, S.G., Kessler, L., Luengo, J.I., Avcrill, L., Johnson, R.K., Gleason, J.G., Pelus, L.M., Dillon, S.B., and Rosen, J. (1998). Science 281, 257-259.

Ullrich, A., and Schlessinger, J. (1990). Cell 61, 203-212.

White, M.F., and Kahn, C.R. (1994). J. Biol. Chem. 269, 1-4.

White, M.F, and Yenush, L. (1998). Curr. Top. Microbiol. Immunol, 228, 179-208.

Yamamoto, Y., Nishimura, K., and Kiriyama, N. (1976). Chem. Pharm. Bull. 24, 1853-1859.

Yu, K.T., and Czech, M.P. (1984). J. Biol. Chem. 259, 5277-5286.

Zhang, B., and Roth, R.A. (1992). J. Biol. Chem. 267, 18320-18328.

Zhang, B., Szalkowski, D., Diaz, E., Hayes, N., Smith, R., and Berger, J. (1994). J. Biol. Chem. 269, 25735-25741. 